\title{
A Rare Case of Congenital Rubella Syndrome
}

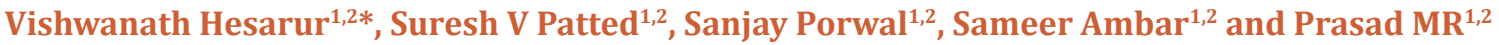 \\ ${ }^{1}$ Department of Cardiology, Jawaharlal Nehru Medical College, KLE Academy of Higher Education and Research (Deemed to be University), \\ Belagavi-590010, Karnataka, India
}

${ }^{2}$ KLES Dr Prabhakar Kore Hospital and Medical Research Centre, Belagavi 590010, Karnataka, India

Submission: January 02, 2018 ; Published: January 25, 2018

*Corresponding author: Vishwanath Hesarur, Department of Cardiology, Jawaharlal Nehru Medical College, KLE Academy of Higher Education and Research, Deemed to be University, Belagavi, Karnataka, India, Tel: +919480008361; Email: drvishwanathhesarur@yahoo.com

\begin{abstract}
Introduction: Congenital rubella syndrome (CRS) is a consequence of rubella infection that can occur when the virus is transmitted in utero during maternal primary infection. It still affects 110,000 children around the world. It has a wide spectrum of presentation which ranges from silent viremia to spontaneous abortions, blindness, deafness, congenital heart disease, and mental retardation.

Case report: Here, we report a case of CRS in a girl aged 8 years who presented with congenital cataract, severe post ductal coarctation of aorta with patent ductus arteriosus and bilateral sensory neural hearing impairment.

Conclusion: We present a case report of congenital rubella syndrome (CRS); though uncommon nowadays, it is still present in India. The main characteristics of our case report were congenital cataract, severe post ductal coarctation of aorta with patent ductus arteriosus (PDA) and sensory neural hearing impairment. This case is reported to highlight the importance of vaccination by which rubella infection can be eradicated. Keywords : Congenital rubella syndrome; Congenital hearing loss; Congenital cataract; Congenital heart disease; Intrauterine infection
\end{abstract}

\section{Introduction}

Congenital rubella syndrome (CRS) is a consequence of rubella infection that can occur when the virus is transmitted in utero during maternal primary infection. It still affects 110,000 children around the world [1]. It has a wide spectrum of presentation which ranges from silent viremia to spontaneous abortions, blindness, deafness, congenital heart disease, and mental retardation [2]. Here, we report a case of CRS in a girl aged 8 years who presented with congenital cataract, severe post ductal coarctation of aorta with patent ductus arteriosus and bilateral sensory neural hearing impairment. This case is reported to highlight the importance of vaccination by which rubella infection can be eradicated.

\section{Case Report}

A 8 year old girl presented to our OPD with history of exertional breathlessness and palpitation of 2 months duration with a background history of congenital blindness of right eye and decreased hearing since birth. Her past history revealed that she was born out of a non-consanguineous marriage, full term normal vaginal delivery at hospital. Baby cried immediately after birth. Weight at birth was $2.7 \mathrm{~kg}$. There was no history of chronic illness in her parents, though the mother had an episode of fever in the first trimester of pregnancy, there was no history of rash during that episode. Mother did not receive vaccination against rubella.
There were no developmental delays in achieving motor and social milestones; however there was delay in achieving speech output.

\section{On general physical examination}

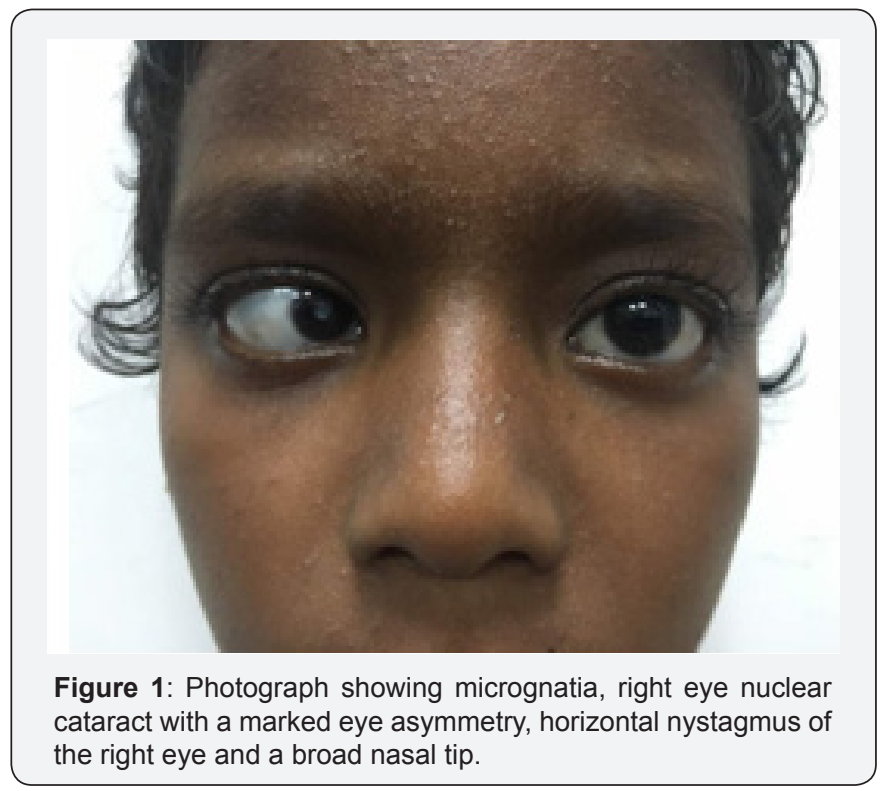


She was undernourished, with a low weight for age, had micrognatia, right eye nuclear cataract with a marked eye asymmetry, horizontal nystagmus of the right eye and a broad nasal tip (Figure 1).

She was acyanotic with a saturation of $96 \%$ at room air. She had a radio-femoral delay but no radio-radial delay. There was a grade 3/6 harsh pansystolic murmur best heard in the left infraclavicular area. Rest of the examination was unremarkable.
She did not respond to sound clinically and was subjected to brainstem evoked response audiometry (BERA).

Her echocardiographic examination revealed situs solitus, severe post ductal coarctation of aorta with a peak pressure gradient of $50 \mathrm{mmHg}$, a small patent ductus arteriosus (PDA) with only systolic flow from the aorta to the right descending pulmonary artery and a bicuspid aortic valve (Figure 2).
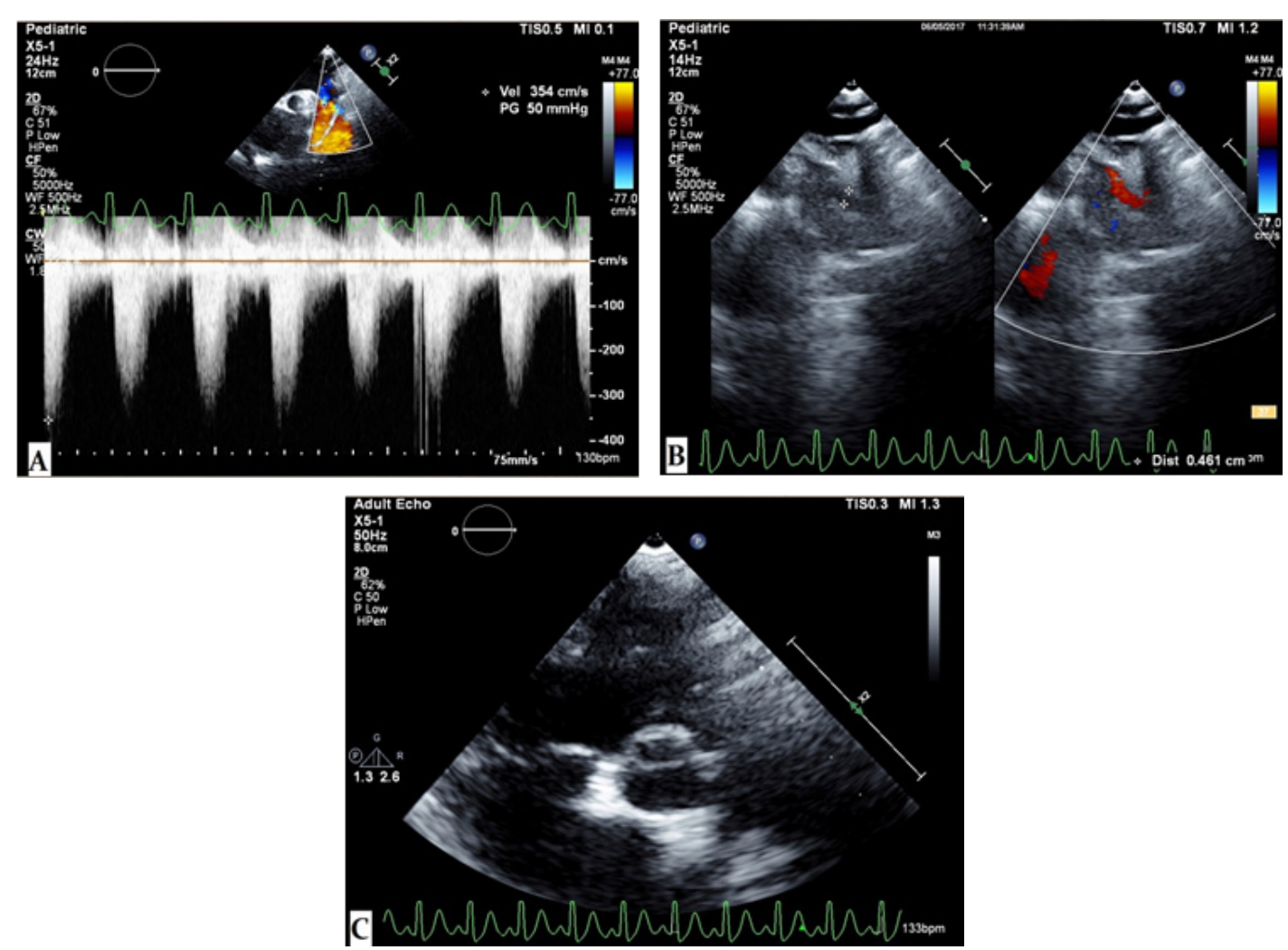

Figure 2: Transthoracic echocardiography showing severe post ductal coarctation of aorta with a peak pressure gradient of $50 \mathrm{mmHg}(2 \mathrm{~A})$, a small patent ductus arteriosus (2B) and a bicuspid aortic valve (2C).

\section{Investigations}

Her hematological parameters, renal, Coagulation and thyroid function tests were within normal limits. Her rubella IgM and IgG were positive.

\section{Discussion}

Rubella is a togavirus belonging to genus rubivirus. Rubella is usually a mild febrile rash disease in children, but to young women's' pregnancy, especially in their first 16 weeks, it has devasting consequences [3]. Both deafness and cardiac manifestations occur if viremia takes place before 11 weeks, and viremia between 13-16 weeks results in isolated deafness [4]. Infection occurring in the first 12 weeks of pregnancy causes CRS in $90 \%$, with almost a $100 \%$ risk of congenital defects. From 13 to 17 weeks, the risk of infection is about $60 \%$, and risk defects about $50 \%$. From 18 to 24 weeks, the risk of infection is about
$25 \%$, with hardly any risk of congenital defects [5]. Though the exact teratogenic mechanism of in utero rubella infection remains unidentified, viral replication in the cells during fetal organogenesis seems to be accountable for CRS [6].

The first description of CRS belongs to Gregg in 1941 but it was completely described in 1944 [7]. A study of Miller et al. [8] showed that the risk of congenital infection was $81 \%$ and the risk of malformation was of $69 \%$ if the mother had rubella in the first pregnancy trimester. The risk fall to $33 \%$ after 12 weeks of gestation and no defects were encountered after week 16. Intrauterine growth retardation and prematurity frequently manifest in CRS. The commonest defect is central hearing loss. Characteristic cardiac defects that occur in CRS include PDA, pulmonary stenosis, and ventricular septal defect (VSD). Cardiac lesions are more frequently prevalent in neonates with ocular lesion $[2,9]$. 
There are still congenital rubella syndrome cases reported around the world despite the introduction of rubella vaccine in the national immunization programme of many countries [3].

\section{Conclusion}

We present a case report of congenital rubella syndrome (CRS); though uncommon nowadays, it is still present in India. The main characteristics of our case report were congenital cataract, severe post ductal coarctation of aorta with patent ductus arteriosus and sensory neural hearing impairment. This case is reported to highlight the importance of vaccination by which rubella infection can be eradicated.

\section{Conflict of Interest}

The author(s) declare(s) that there is no conflict of interest regarding the publication of this paper.

\section{Informed Consent}

Written informed consent was obtained from parent for publication of this case report and accompanying images.

\section{References}

1. Frost F, MJ Roach, I Kushner, Schreiber P (2005) Inflammatory Eilard T, Strannegard O (1974) Rubella reinfection in pregnancy followed by transmission to the fetus. J Infect Dis 129(5): 594-596.

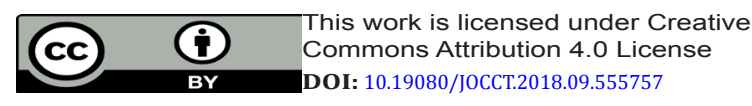

1. Vijayalakshmi P, Kakkar G, Samprathi A, Banushree R (2002) Ocular manifestations of congenital rubella syndrome in a developing country. Indian J Ophthalmol 50(4): 307-311.

2. Reef SE, Plotkin S, Cordero JF, Katz M, Cooper L, et al. (2000) Preparing from congenital rubella syndrome elimination: summary of the workshop on congenital rubella syndrome elimination in the United States. Clin Infect Dis 31(1): 85-95.

3. Jenkins KJ, Correa A, Feinstein JA, Botto L, Britt AE, et al. (2007) Non inherited risk factors and congenital cardiovascular defects: Current knowledge: A scientific statement from the American Heart Association Council on Cardiovascular Disease in the Young: Endorsed by the American Academy of Pediatrics. Circulation 115(23): 29953014.

4. Deka D, Rustgi R, Singh S, Roy KK, Malhotra N (2006) Diagnosis of acute rubella infection during pregnancy. J Obstet Gynaecol India 56(1): 44-46.

5. De Oliveira SA, Camacho LA, de Medeiros Pereira AC, Bulhoes MM, Aguas AF, et al. (2006) Performance of rubella suspect case definition: Implications for surveillance. Rev Saude Publica 40(3): 450-456.

6. Webster WS (1998) Teratogen update: congenital rubella. Teratology 58(1): 13-23.

7. Miller E, Cradock-Watson JE, Pollock TM (1982) Consequences of confirmed maternal rubella at successive stages of pregnancy. Lancet 2(8302): 781-784.

8. Givens KT, Lee DA, Jones T, Ilstrup DM (1993) Congenital rubella syndrome: Ophthalmic manifestations and associated systemic disorders. Br J Ophthalmol 77(6): 358-363.

\begin{tabular}{|l|}
\hline \multicolumn{1}{|c|}{ Your next submission with Juniper Publishers } \\
will reach you the below assets \\
- Quality Editorial service \\
- Swift Peer Review \\
- Reprints availability \\
- E-prints Service \\
- Manuscript Podcast for convenient understanding \\
- Global attainment for your research \\
- Manuscript accessibility in different formats \\
( Pdf, E-pub, Full Text, Audio) \\
- Unceasing customer service \\
Track the below URL for one-step submission \\
https://juniperpublishers.com/online-submission.php
\end{tabular}

